NBER WORKING PAPER SERIES

\title{
GLOBAL FINANCIAL CYCLE AND LIQUIDITY MANAGEMENT
}

\author{
Olivier Jeanne \\ Damiano Sandri \\ Working Paper 27901 \\ http://www.nber.org/papers/w27901
NATIONAL BUREAU OF ECONOMIC RESEARCH
1050 Massachusetts Avenue
Cambridge, MA 02138
October 2020

This paper benefitted from comments from seminar participants in the 2017 IMF Annual Research Conference, the London Business School, the 2020 AEA Annual Meetings, and the World Bank. We thank our discussants Gianluca Benigno and Kinda Hachem for their comments. The views expressed herein are those of the authors and do not necessarily reflect the views of the IMF, its Executive Board, IMF management, or the National Bureau of Economic Research.

NBER working papers are circulated for discussion and comment purposes. They have not been peer-reviewed or been subject to the review by the NBER Board of Directors that accompanies official NBER publications.

(C) 2020 by Olivier Jeanne and Damiano Sandri. All rights reserved. Short sections of text, not to exceed two paragraphs, may be quoted without explicit permission provided that full credit, including (C) notice, is given to the source. 
Global Financial Cycle and Liquidity Management

Olivier Jeanne and Damiano Sandri

NBER Working Paper No. 27901

October 2020

JEL No. F31,F32,F36,F38

\begin{abstract}
$\underline{\text { ABSTRACT }}$
We use a tractable model to show that emerging markets can protect themselves from the global financial cycle by expanding (rather than restricting) capital flows. This involves accumulating reserves when global liquidity is high to buy back domestic assets at a discount when global financial conditions tighten. Since the private sector does not internalize how this buffering mechanism reduces international borrowing costs, a social planner increases the size of capital flows beyond the laissez-faire equilibrium. The model also provides a role for foreign exchange intervention in less financially developed countries. The main predictions of the model are consistent with the data.
\end{abstract}

Olivier Jeanne

Department of Economics

Johns Hopkins University

582 Wyman Bldg.

3400 N. Charles Street

Baltimore, MD 21218

and NBER

ojeanne@jhu.edu

Damiano Sandri

International Monetary Fund

700 19th Street N.W.

Washington D.C. 20431

dsandri@imf.org 


\section{Introduction}

Emerging market (EM) economies are subject to large fluctuations in their access to foreign funds as a result of the global financial cycle. Figure 1 shows that gross capital inflows to EMs increased more than three folds in the years prior 2007 and then collapsed during the global financial crisis. The volatility of gross inflows has been largely absorbed through offsetting capital outflows which capture the purchase of foreign assets by residents in EMs. In other words, when foreign investors increase their holdings of EMs' assets, EM residents accumulate foreign assets and viceversa. To further smooth the domestic impact of fluctuations in capital inflows, EMs also employ several capital flow management policies, such as capital controls or foreign exchange interventions. ${ }^{1}$ Figure 1 shows, for example, that the public sector actively leans against fluctuations in capital inflows by accumulating official reserves when gross inflows increase and selling reserves when inflows recede.

The chart also shows the evolution of the stock market total-return index in EMs. ${ }^{2}$ We see that in the years prior to the global financial crisis, stock prices in EMs rose rapidly above trend exactly when foreign investors increased their holdings of EM assets while EM residents brought their money abroad. The opposite dynamic took place post 2007, when EM stock prices plunged while gross capital flows declined sharply. This suggests that EM residents seize a trading advantage by buffering the volatility of gross capital inflows with gross outflows: they sell EM assets when prices are high and save the proceeds abroad; and then use foreign funds to buy back EM assets when prices decline.

This paper proposes a model that accounts for these facts, provides additional predictions consistent with empirical evidence, and lead to novel normative implications for capital flow management.

We present a simple three-period model of an EM economy with a large number of private agents who borrow from foreign investors in the first period to finance an illiquid domestic investment and to accumulate liquid foreign assets. There is a risk of an external financial tightening in the second period. External tightening means that foreign investors wish to withdraw their funds because they highly value liquidity, leading to a fire sale of EM debt. In our model, external financial tightening takes the form of deleveraging by foreign

\footnotetext{
${ }^{1}$ Rey (2015), the IMF (2012), Ostry et al. (2011) and Jeanne, Subramanian and Williamson (2012) have advocated the use of such policies.

${ }^{2}$ This is computed in deviation from a log-linear trend, as reported on the right axis.
} 
Figure 1: Gross capital flows and stock market index, average across EMs

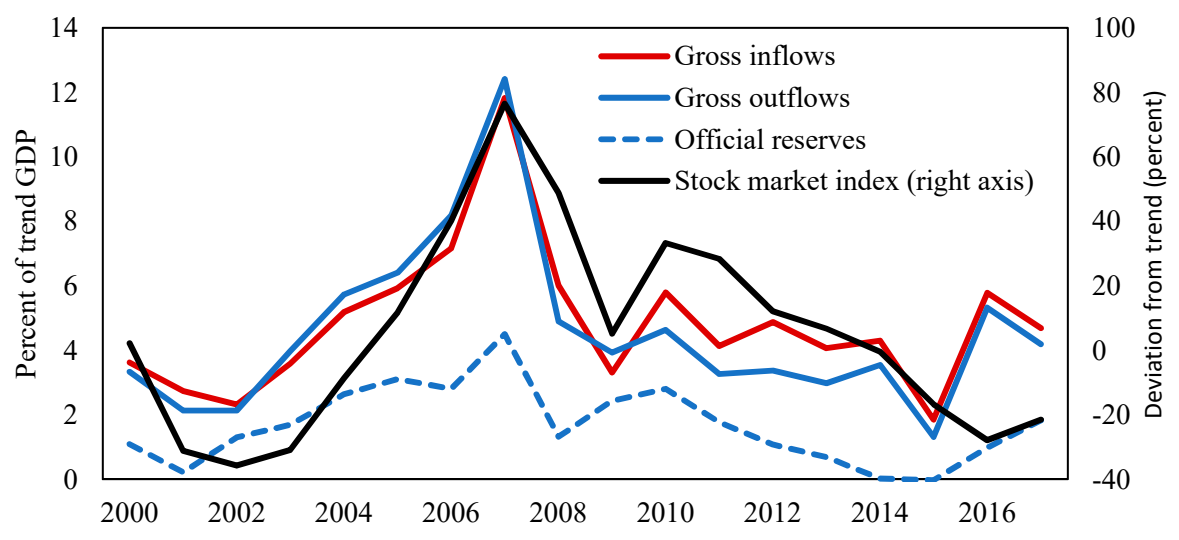

banks, in line with the evidence about the role of banking in the transmission of the global financial cycle (Miranda-Agrippino and Rey, 2020). When external financial conditions tighten, EM agents as well as foreign arbitrageurs use their liquidity to buy home debt. External financial tightening thus leads to a "retrenchment" (as defined by Forbes and Warnock (2012)) in which EM agents repatriate foreign funds at the same time as foreigners sell EM assets. In a decentralized equilibrium, EM agents hold a level of liquidity such that the expected benefit from buying back domestic debt at the fire-sale price is exactly offset by the opportunity cost of carrying the liquidity. ${ }^{3}$

The model highlights the importance of domestic financial development, defined as a country's ability to produce financial assets and sell them to foreign investors. More financially developed countries channel a larger share of gross capital inflows into external liquidity rather than towards domestic physical investment. This might look like a diversion of capital flows away from their most productive use but the country's large external balance sheet in fact helps it to finance more investment at home. External liquidity reduces the country's cost of external borrowing and stimulates domestic productive investment.

Yet, even in financially developed countries, the private sector underinvests in liquidity. This is because of a pecuniary externality since private

\footnotetext{
${ }^{3}$ The opportunity cost of reserves is measured as the spread between the interest rate on external debt and the return on liquid reserves, as in Rodrik (2006). See Adler and Mano (2016) for a recent review of how to measure the opportunity cost of reserves.
} 
agents do not internalize the impact of their decisions on the price of domestic debt. Increasing foreign liquidity raises the price of EM debt, both ex ante and in a fire sale. This reduces the carry cost of liquidity but also the associated benefits. We show that on balance, the level of liquidity is too low under laissez-faire. A constrained social planner finds it optimal to increase foreign borrowing so as to accumulate more foreign liquidity. Paradoxically, although welfare of an EM economy is reduced by the uncertainty in external financial conditions, welfare is maximized by maximizing the size of the country's external balance sheet, and thus the volatility of gross capital inflows. This is contrary to conventional wisdom which calls for restricting capital flows to buttress resilience to global financial shocks. The social planner also reduces physical investment below the laissez-faire level so as to exploit the country's monopsonist power in issuing its own debt. We show that the social planner allocation can be implemented by using a subsidy on the accumulation of foreign liquidity by the private sector.

The model also provides a rationale for foreign exchange intervention. In countries at a relatively low level of financial development, the government can complement the buffering role of private capital flows by accumulating official reserves when global financial conditions are loose and selling them to re-purchase domestic assets when conditions tighten. As financial development increases, foreign exchange intervention becomes less valuable since the private sector can better insure itself.

We then take a closer look at the data in light of the model. We define a country's international borrowing spread as the difference between the return that it pays on its external liabilities and the return that it earns on its external assets (the opposite of the "exorbitant privilege" studied by Gourinchas and Rey (2007)). The model makes three empirical predictions: 1) gross capital inflows are positively correlated with gross capital outflows and with the borrowing spread over time; 2) the borrowing spread is negatively correlated with the size of external liabilities across countries; and 3) the use of foreign exchange interventions is negatively correlated with the size of foreign liabilities across countries. We find these three predictions to be consistent with the data from EM economies.

Relationship to the literature. As noted in the introduction, most of the theoretical literature on capital flow management has focused on controls on capital inflows - see for example Ostry et al. (2012) and Korinek (2011). The rationale for policy intervention generally arises from pecuniary exter- 
nalities associated with collateral constraints, as analyzed for example in Jeanne and Korinek (2010), Bianchi (2011), Benigno et al. (2016), SchmittGrohé and Uribe (2017), and Korinek (2018). In these models there is no meaningful separate role for the management of inflows and outflows (in particular foreign exchange reserves). What matters in a crisis is the net worth of indebted agents and it is irrelevant if net worth is increased by lowering external debt or increasing external assets. These papers have shown that controls on capital inflows should be used to reduce net capital inflows. By contrast we show here that capital flow management should increase gross capital inflows. The pecuniary externalities at work in our model are distributive in the sense of Davila and Korinek (2018).

In a more closely related contribution, Caballero and Simsek (2020) present a model of gross capital flows in which capital flow surges and retrenchments are generated by fickle global investors. Our analysis shares several features with theirs, in particular the association of capital flow retrenchments with fire sales. There are also several differences that turn out to be significant for the results: in our model capital flows involve short-term and long-term debt rather than real assets, and the EM economy is populated by a representative agent (whereas they assume two agents, banks and distressed sellers). This leads us to emphasize the redistributive implications of capital flow management between emerging market borrowers and advanced economy investors. Another difference is that we analyze the role for reserves interventions by the government. The optimal management of gross capital flows is also analyzed in Aizenman (2011). In their model reserves are used to prevent contagion in the liquidation of domestic projects. The optimal policy involves both a tax on external borrowing and a subsidy on the accumulation of private reserves.

The paper is also related to a theoretical literature on the optimal level of reserves for an economy with fluctuating access to foreign financial flows. Jeanne and Rancière (2011) present a model of the optimal level of reserves to deal with the risk of rollover risk in external debt. Reserves are modeled as an insurance contract that pays off conditional on the realization of a sudden stop, like in Caballero and Panageas (2008). Bianchi, Hatchondo and Martinez (2018) analyze a similar problem when reserves take the form of a noncontingent asset and can be financed by sovereign defaultable debt. Gourinchas, Rey and Govillot (2017) present a model in which EMs holds low-yielding US assets because these assets yield a higher return in bad times. In these models there is no meaningful difference between reserves held by the government or by the private sector. Similar to our paper, Céspedes, Chang 
and Velasco (2017) and Céspedes and Chang (2019) analyze models in which official reserves are needed because the private sector does not internalize the beneficial effects of liquidity in periods of financial distress.

On the empirical side, our paper is related to the literature that studies the behavior of gross capital flows in the global financial cycle. Forbes and Warnock (2012) and Broner et al. (2013) have documented how gross capital inflows and outflows tend to move together. Broner et al. (2013) document that gross capital flows are very large and volatile, especially relative to net capital flows. During crises, total gross flows collapse and there is a retrenchment in both inflows by foreigners and outflows by domestic agents. Davis and van Wincoop (2017) document that the correlation between capital inflows and outflows has increased substantially over time in advanced and developing countries. IMF (2013) shows that EM economies that buffer foreign capital inflows with offsetting resident flows tend to be more resilient against fluctuations in global capital markets. Miranda-Agrippino and Rey (2020) find that tight phases of the global financial cycle are accompanied by a deleveraging of global banks and a surge in risk premia in global asset markets. Bruno and Shin (2015) present a model highlighting the bank leverage cycle as the determinant of the transmission of financial conditions across borders through banking sector capital flows. They find support for the key predictions of their model in a panel study of 46 countries.

A line of the empirical literature has pointed to the stabilizing benefits of reserves. Bussière et al. (2015) show that countries with high reserves relative to short-term debt suffered less from the global financial crisis, particularly when associated with a less open capital account. Ghosh, Ostry and Qureshi (2016) find that countries with higher stocks of foreign exchange reserves are significantly less likely to experience a crisis following surges in capital inflows. Aizenman, Cheung and Ito (2015) find that emerging market economies with lower reserve holdings in 2012 tended to experience exchange rate depreciation against the U.S. dollar when many emerging markets were adjusting to the news of tapering quantitative easing in 2013. Blanchard, Adler and de Carvalho Filho (2015) show that countercyclical reserve interventions have stemmed exchange rate pressures from global capital flow shocks in emerging market economies.

The paper is structured as follows. The next section presents the model assumptions and section 3 characterizes the laissez-faire equilibrium. Section 4 looks at the impact of domestic financial development on capital flows. Section 5 analyzes optimal policies. Section B presents our empirical results 
and section 7 concludes.

\section{Model}

We consider an EM economy over three periods $t=0,1,2$. The economy is populated by a unitary mass of atomistic identical agents who borrow from foreign investors in period 0 . The proceeds of the borrowing are used to finance domestic investment projects as well as foreign liquid assets (reserves). The domestic projects are illiquid in the sense that they pay off in period 2 and cannot be sold in period 1 . The global financial cycle is modeled by assuming that foreign investors' willingness to hold EM debt varies over time, in a sense to be made more precise below.

Agents do not consume in periods 0 and 1 . The welfare of all agents (EM borrowers and foreign investors) is equal to their expected period-2 consumption, where we assume that the intertemporal discount factor is zero to simplify the notation. Figure 2 reports the timeline and the main assumptions, which we describe in more details below.

EM BORROWERS

\begin{tabular}{|c|c|c|c|c|}
\hline \multicolumn{2}{|c|}{$\begin{array}{l}\quad \boldsymbol{t}=\mathbf{0} \\
\text { Investment and } \\
\text { balance sheet buildup }\end{array}$} & \multicolumn{2}{|c|}{$\begin{array}{l}\qquad \boldsymbol{t}=\mathbf{1} \\
\text { Balance sheet adjustment to } \\
\text { external financial conditions }\end{array}$} & $\begin{array}{l}\quad \boldsymbol{t}=\mathbf{2} \\
\text { Production and } \\
\text { consumption, } \mathrm{U}=\mathrm{E}_{0}\left(\mathrm{c}_{2}\right)\end{array}$ \\
\hline & \multirow{3}{*}{$p b$} & $a-a^{\prime}=p^{\prime}$ & $\left(b-b^{\prime}\right)$ & \multirow{3}{*}{$c^{E M}=f(k)-b^{\prime}+a$} \\
\hline$a$ & & $a^{\prime}$ & & \\
\hline$k$ & & $k$ & & \\
\hline
\end{tabular}

FOREIGN INVESTORS

Bankers

invest in EM debt and cash
With probability $\pi$, bankers sell EM debt to arbitrageurs and EM agents at price $q$

Figure 2: Model timeline 
EM borrowers. The budget constraints of the representative EM borrower are,

$$
\begin{aligned}
k+a & =p b, \\
a+p^{\prime} b^{\prime} & =a^{\prime}+p^{\prime} b, \\
b^{\prime}+c^{E M} & =f(k)+a^{\prime} .
\end{aligned}
$$

In period 0 the representative EM agent finances an illiquid domestic investment $k$ as well as liquid foreign assets $a$ by issuing long-term bonds $b$ at price $p$. The bonds are default-free and repaid in period 2. The payoff of the investment is an increasing and concave function of $k$ and occurs in period 2, when EM agents consume. The foreign assets are invested in cash, which is modeled as a zero-return storage technology. One may think of $a$ as the reserves of the private sector (the case of public reserves will be considered in section 5). The representative EM borrower adjusts his balance sheet to external financial conditions by buying back a quantity of bonds $b-b^{\prime}$ at price $p^{\prime}$ in period 1 , after which he is left with a quantity of reserves $a^{\prime}$. EM assets and liabilities are assumed to be non-negative.

Foreign investors. There is a large number of foreign investors endowed with resources in periods 0 and 1 . The EM economy cannot obtain funds directly from foreign investors and must borrow from specialists. There are two classes of specialists, the bankers and the arbitrageurs.

Bankers are atomistic and have unitary mass. They have no funds of their own in period 0 and lend to EM borrowers by issuing deposits to nonspecialist investors. The period-0 budget constraint of bankers is,

$$
p b=d,
$$

where $d$ is the quantity of deposits that they issue. ${ }^{4}$ Bankers also have $\kappa$ units of legacy assets that generate $R \kappa$ units of output if they are held until maturity at time 2 , with $R>1$. These assets can be liquidated for a value $\kappa$ at time 1.

We assume that the deposits are demandable in period 1 and that depositors demand early repayment with probability $\pi .^{5}$ Thus, there are two

\footnotetext{
${ }^{4}$ Nothing of substance is changed if we allow the bankers to invest in cash.

${ }^{5}$ Demandable deposit contracts are a standard feature in the banking literature. Deposits could be demandable to give appropriate incentives to bankers or to protect depositors against the risk of a sudden loss in bankers' income pledgeability.
} 
states: the normal state (denoted by $N$ ), in which depositors are repaid $d$ in period 2, and the "sudden stop" state (denoted by $S$ ), in which the depositors demand early repayment.

In the normal state the period-2 consumption of bankers is equal to the payoff on the unliquidated legacy asset plus the profit that bankers make from the spread on the EM debt,

$$
c_{N}^{B}=R \kappa+b-d=R \kappa+(1-p) b .
$$

In a sudden stop, bankers repay the deposits by using their cash holdings, selling EM debt, and possibly liquidating their legacy assets. Let us denote by $q$ the price of EM debt at time 1 in the sudden stop state. If $q>p$ the bankers make a profit $(q-p) b$ after they have sold their EM debt holdings, which they invest in cash for consumption in period 2. If $q \leq p$ the bankers make a loss $(p-q) b$. In this case, the representative banker liquidates a quantity $(p-q) b$ of legacy asset to repay all the depositors in a sudden stop. The bankers' consumption in the sudden stop state is thus given by,

$$
c_{S}^{B}= \begin{cases}R \kappa+(q-p) b & \text { if } q>p \\ R \kappa-R(p-q) b & \text { if } q \leq p .\end{cases}
$$

Observe that since $R>1$, the disutility of bank losses is larger than the utility of bank profits, making bankers effectively risk averse.

EM debt can also be sold to arbitrageurs. These agents are endowed with $\phi$ in period 1 which they can invest in cash or EM debt. Their final consumption is equal to the payoff from investing $\phi$ in EM bonds (or in cash if $p^{\prime}=1$ ) in period 1 ,

$$
c^{A}=\frac{\phi}{p^{\prime}}
$$

This setup captures the key frictions at work in conventional accounts of the global financial cycle. EM economies obtain funds from specialized investors who are sometimes under pressure to sell EM assets. The selling pressure, in our model, comes from the fact that the period-0 lenders have to deleverage. ${ }^{6}$ This selling pressure would not depress the price of EM debt in the presence of arbitrageurs with a large pool of resources. A key assumption

\footnotetext{
${ }^{6}$ Alternatively, we could assume that the original lenders are self-funded but have access to an alternative investment with gross return $R$ between periods 1 and 2 with probability $\pi$. In this case the selling pressure comes from the fact that foreign investors want to disinvest from the EM economy to take advantage of the higher return.
} 
will be that the arbitrageurs' resources $\phi$ are not large enough to prevent a fire sale of EM debt.

First best. We characterize the unconstrained first-best allocation as a benchmark for the rest of the analysis. The first-best allocation is achieved if EM borrowers can bypass the intermediation of specialists and borrow directly from non-specialist foreign investor at a zero interest rate. EM physical investment then satisfies,

$$
f^{\prime}\left(k^{F B}\right)=1,
$$

and the level of reserves $a$ is indeterminate. As we will see, the first best allocation is achieved if the probability of sudden stop, $\pi$, is equal to zero, or if the resources of arbitrageurs, $\phi$, are large enough to prevent a fall in the price of EM debt in a sudden stop.

\section{Laissez-faire}

We now solve for the laissez-faire equilibrium in which: (i) EM borrowers set the levels of $k, a$, and $b$ so as to maximize their utility $E_{0}\left(c^{E M}\right)$ subject to the budget constraints (1)-(3) and taking the prices $p$ and $p^{\prime}$ as given; and (ii) the prices $p$ and $p^{\prime}$ clear the market for EM debt in periods 0 and 1 . The equilibrium from period 1 onwards is contingent on the state $(N$ or $S)$. We derive the laissez-faire equilibrium by proceeding backwards, starting with period 1.

Period-1 equilibrium. In the normal state the period-1 price of EM debt is $p^{\prime}=1$. All agents (EM residents, bankers and arbitrageurs) view EM debt as equivalent to cash and their portfolio allocation between EM debt and cash is indeterminate.

In the sudden stop state the bankers sell their holdings of EM debt to the arbitrageurs and the EM residents. The debt price that equalizes demand and supply is such that $a+\phi=q b$ unless there is enough cash in the market to buy the debt at price $1(a+\phi \geq b)$. The two cases are subsumed by the following expression for the fire-sale price of debt,

$$
q=\min \left(1, \frac{a+\phi}{b}\right) .
$$

Period-0 demand for EM debt. In period 0 the foreign bankers maximize their utility $U_{0}^{B}=E_{0}\left(c^{B}\right)=(1-\pi) c_{N}^{B}+\pi c_{S}^{B}$ where $c_{N}^{B}$ and $c_{S}^{B}$ 
are respectively given by (4) and (5). It is easy to see that if $q>p$, the bankers make a strictly positive expected profit on each unit of EM debt purchased in period 0 since they can resell it at a higher price in period 1 . If that were the case their demand for EM debt would be infinite, which is not an equilibrium. Hence, the price of EM debt in case of a sudden stop cannot exceed the issuance price, $q \leq p$. Using (4) and (5), the banker's welfare is given by,

$$
U_{0}^{B}=R \kappa+\left(1-\pi+\pi R q-R^{e} p\right) b
$$

where

$$
R^{e} \equiv 1-\pi+\pi R
$$

is the expected return on period-1 liquidity for bankers.

Bankers maximize their utility (9) subject to the constraint that the legacy asset is large enough to cover their loss, $(p-q) b \leq \kappa$. We assume that $\kappa$ is large enough that this constraint is not binding, so that bankers' expected profit from holding EM debt must be equal to zero in equilibrium. ${ }^{7}$ This implies,

$$
p=\frac{1-\pi+\pi R q}{R^{e}} .
$$

Expression (10) can be re-written as

$$
p=E_{0}\left(p^{\prime}\right)-\pi(1-\pi) \frac{R-1}{R^{e}}(1-q),
$$

where $E_{0}\left(p^{\prime}\right)=1-\pi+\pi q$ is the expected price of EM debt. The last term on the right-hand side of (11) is a pure risk premium discount, which is due to the fact that EM debt falls in value when there is a sudden stop that raises the value of liquidity for bankers.

Solving for $b$ in equations (1), (8) and (10) it is possible to express the period-0 price of EM debt in terms of physical investment $k$ and reserves $a$. The following lemma describes how $p$ varies with $k$ and $a$.

Lemma 1 The fire-sale price of EM debt is a function of the EM agents' investment in physical capital $k$ and reserves $a$,

$$
q(k, a)=\left[1+\frac{R^{e}}{1-\pi} \frac{(k-\phi)^{+}}{a+\phi}\right]^{-1},
$$

(using the conventional notation $x^{+}=\max (x, 0)$ ).

\footnotetext{
${ }^{7} \mathrm{~A}$ condition on $\kappa$ involving the exogenous parameters is derived at the end of this section.
} 
Proof. Using equation (8) and (10) to substitute out $q$ and $p$ from the budget constraint (1) gives

$$
R^{e}(k+a)=(1-\pi) b+\pi R \min (b, a+\phi) .
$$

If $b \leq a+\phi$ this equation reduces to $k+a=b$. If $b \geq a+\phi$ simple manipulations of this equation give

$$
b=a+\phi+\frac{R^{e}}{1-\pi}(k-\phi) .
$$

Using this expression to substitute out $b$ from (8) gives

$$
q=\left[1+\frac{R^{e}}{1-\pi} \frac{(k-\phi)}{a+\phi}\right]^{-1}
$$

The condition $q \leq 1$ is then satisfied only if $k-\phi \geq 0$. Hence there are two cases. Either $k \leq \phi$ and $q=1$, or $k \geq \phi$ and $q$ is given by (14). These two cases are summarized by equation (12).

Using (10), the period-0 price of EM debt can also be expressed as a function of $k$ and $a$

$$
p(k, a)=\frac{1-\pi+\pi R q(k, a)}{R^{e}} .
$$

Several important observations follow from equations (12) and (15). First, $p(k, a)=1$ if $k \leq \phi$. If EM debt is lower than $\phi$, there is enough cash in the market to prevent a fall in the price of EM debt in a sudden stop. In this case there is no risk in the price of debt, so it can be sold to bankers in period 0 for $p=1$.

Second, if $k>\phi, q$ and $p$ are both strictly smaller than 1 because the resources of the arbitrageurs are too low to prevent a fall in the EM debt price if there is a sudden stop. In this case the price of EM debt is decreasing in physical investment and increasing in reserves,

$$
\frac{\partial p}{\partial k}<0, \frac{\partial p}{\partial a}>0
$$

On one hand, higher investment $k$ is financed by issuing more debt $b$, which depresses the fire-sale price of debt. On the other hand, issuing debt in order 
to accumulate reserves raises the fire-sale price of debt. To understand this result one can substitute out $a$ from (8) using (1), which gives

$$
q=p-\frac{k-\phi}{b}
$$

Selling debt at price $p$ in period 0 and accumulating the proceeds as reserves to buy back the debt at a lower price in period 1 raises the fire-sale price of debt given $p$. By raising the fire-sale price, reserves accumulation also increases the ex-ante price $p$.

Period-0 reserves. Next, consider the problem of EM agents in period 0 . The EM agents' welfare can be computed by assuming that they spend all their reserves to buy back EM debt in period $1 .{ }^{8}$ Using $a^{\prime}=0$ and the budget constraints (1)-(3) to substitute out $k$ and $c^{E M}$, the representative borrower's welfare can be written,

$$
\begin{aligned}
U_{0}^{E M} & =f(k)-b+a E_{0}\left(\frac{1}{p^{\prime}}\right) \\
& =f(k)-\frac{k}{p}+a\left[E_{0}\left(\frac{1}{p^{\prime}}\right)-\frac{1}{p}\right] .
\end{aligned}
$$

The representative EM agent maximizes his welfare taking the prices $p$ and $p^{\prime}$ as given. The first-order condition for $k$ equates the marginal cost of issuing bonds to the marginal return on capital,

$$
f^{\prime}(k)=\frac{1}{p}
$$

The second term on the right-hand side of (17) is the EM agent's benefit from holding reserves. This is the expected profit from issuing bonds at price $p$ in period 0 and investing the proceeds in cash to buy back EM debt at price $p^{\prime}$ in period 1 . In an equilibrium where EM borrowers hold reserves (i.e., in which the constraint $a \geq 0$ is not binding) the marginal net benefit of accumulating reserves must be equal to zero

$$
E_{0}\left(\frac{1}{p^{\prime}}\right)-\frac{1}{p}=0 .
$$

It is then possible to show the following result.

\footnotetext{
${ }^{8}$ If $p^{\prime}=1$ their purchase of EM debt is indeterminate but their welfare is the same as if they spent all their reserves on EM debt.
} 
Lemma 2 If $k^{F B}>\phi$ the representative EM agent holds a strictly positive level of reserves if and only if $q=1 / R$.

Proof. Using that $p^{\prime}$ is equal to 1 with probability $1-\pi$ and to $q$ with probability $\pi$ and equation (10), the l.h.s. of (19) can be written

$$
1-\pi+\frac{\pi}{q}-\frac{1-\pi+\pi R}{1-\pi+\pi R q}=\pi(1-\pi) \frac{1-q}{q} \frac{1-R q}{1-\pi+\pi R q} .
$$

Condition (19) is satisfied if and only if $q=1 / R$ or $q=1$. If $q<1 / R$ $(q>1 / R)$, the marginal benefit of accumulating (decumulating) reserves is strictly positive (negative), so that EM agents accumulate (decumulate) reserves until $q=1 / R$. The solution $q=1$ is ruled out by $k^{F B}>\phi$. If $q=1$ then $k=k^{F B}$ by (18) but (12) implies $q<1$, a contradiction.

The intuition for this result is as follows. In the sudden-stop state foreign bankers and EM agents receive period-1 payoffs of respectively $R$ and $1 / q$ per unit of period-1 liquidity. Foreign bankers and EM agents have short or long positions in cash and EM debt and substitute between the two assets at the same price. Hence in equilibrium EM agents must receive the same payoff as bankers in the sudden-stop state, which implies $1 / q=R$.

Period-0 equilibrium. Putting things together, the equilibrium level of capital and price of debt are determined as in Figure 3. The upward sloping curve corresponds to the EM demand for funds, equation (18). The downward sloping curve represents the foreign investors's supply of funds, equation (15), taking into account the endogeneity of $a$ to the fire-sale price. When $k$ exceeds $\phi$, the fire-sale price $q$ falls below 1 but as long as $q$ is larger than $1 / R, \mathrm{EM}$ residents do not invest in reserves (by Lemma 2) so that $p$ is equal to $p(k, 0)$. When the fire-sale price reaches $1 / R$ (point $B$ ), EM residents start to accumulate reserves so that the fire-sale price remains equal to $1 / R$, and $p$ is equal to $1 / R^{e}$. EM agents start accumulating reserves when $q(k, 0) \leq 1 / R$, which using (12) is equivalent to $k \geq \phi R / R^{e}$.

Figure 3 shows an equilibrium (point A) where EM agents accumulate a positive level of reserves. The following Proposition characterizes such equilibria in general.

Proposition 3 (Laissez-faire equilibrium with private reserves) The EM agents hold a strictly positive level of reserves in the laissez-faire equilibrium if and only if

$$
f^{\prime}\left(\phi \frac{R}{R^{e}}\right)>R^{e}
$$




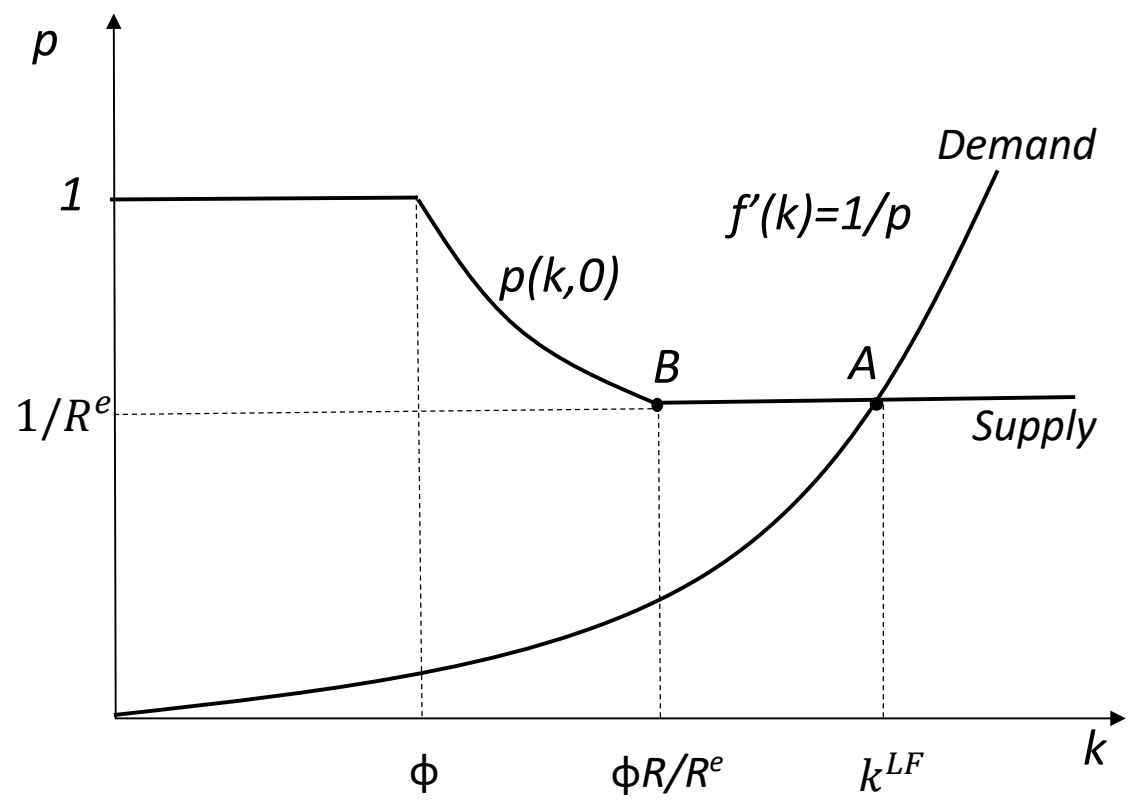

Figure 3: Laissez-faire equilibrium $k$ and $q$

In this equilibrium the price of EM debt is equal to $1 / R^{e}$ in period 0 and falls to $1 / R$ in period 1 if there is a sudden stop. The period-0 level of physical investment satisfies

$$
f^{\prime}\left(k^{L F}\right)=R^{e},
$$

and the EM country's external balance sheet is given by

$$
\begin{aligned}
b^{L F} & =\frac{k^{L F}-\phi}{1 / R^{e}-1 / R}, \\
a^{L F} & =\frac{k^{L F}-\phi R / R^{e}}{R / R^{e}-1} .
\end{aligned}
$$

Proof. Assume that the constraint $a \geq 0$ is not binding so that (19) applies. Then by Lemma $2 q$ is equal to $1 / R$ and equation (10) implies $p=1 / R^{e}$. Condition (18) implies $f^{\prime}\left(k^{L F}\right)=R^{e}$. The expressions in (23) and (24) result from the budget constraint $k^{L F}+a=p^{L F} b$ and $1 / R=(a+\phi) / b$ from equation (8). Condition (21), which is equivalent to $k^{L F}>\phi R / R^{e}$, is necessary and sufficient to ensure that the expression for $a$ given in (24) is strictly positive. 
Proposition 3 calls for several observations. First, equation (22) implies that $k^{L F}<k^{F B}$ if $\pi>0$, i.e., the level of physical capital falls short of the first best under laissez faire. This is because the cost of borrowing from foreign bankers is increased by the cost of liquiditating the legacy asset in a sudden stop.

Second, condition (21) is stronger than the condition for the price of EM debt to be affected by a sudden stop in period $1, \phi<k^{F B}$. If $\phi<k^{F B}$ but (21) is not satisfied, the price of debt falls in period 1 , but not by enough to induce the EM agents to accumulate reserves.

Third, the level of physical investment and the debt prices $p$ and $p^{\prime}$ do not depend on the foreign arbitrageurs' resources $\phi$. Changes in $\phi$ lead to changes in the EM balance sheet such that the price of EM debt remains the same. For example, a lower $\phi$ induces EM residents to issue more debt and accumulate more reserves so as to keep the price of debt the same.

Finally, this equilibrium was derived under the assumption that bankers have enough legacy asset to pay for their losses in a sudden stop, $\kappa \geq$ $(p-q) b$. Using the values given in Proposition 3 this condition becomes $\kappa \geq k^{L F}-\phi$. We assume this condition to be satisfied in the rest of this paper.

\section{Financial development and capital flows}

We assumed in the previous section that EM agents were unconstrained in the amount of debt that they can issue. We now relax this assumption and assume that domestic agents can issue a limited amount of debt because of a domestic financial friction that limits the ability of EM agents to issue debt to foreign investors. The question is how domestic financial development affects capital flows, and in particular the allocation of capital inflows between physical investment and reserves. The model predictions derived in this section will be compared with the empirical evidence in section B.

We assume that a financial friction limits the borrowing capacity of EM agents. As a result EM borrowers are subject to the credit constraint,

$$
p b \leq \beta,
$$

where $\beta$ is an exogenous parameter. Several microfoundations for such a constraint can be found in the literature. ${ }^{9}$ Parameter $\beta$ may reflect the

\footnotetext{
${ }^{9}$ For example, assume the collateral constraint $p b \leq \alpha+\gamma(a+k)$, where $\gamma$ is a coeffi-
} 
strength of creditor rights, the strength of their enforcement, or the creditors' ability to monitor the borrowers' actions. We will interpret this variable as the country's level of financial development. Increased financial development allows EM agents to produce more financial assets that can be sold to foreign investors. Constraint (25) is binding if and only if $\beta$ is smaller than the economy's unconstrained level of foreign borrowing, $k^{L F}+a^{L F}=$ $\left(k^{L F}-\phi\right) /\left(1-R^{e} / R\right)$.

We study how the country's external balance sheet, $a$ and $b$, investment $k$, and debt prices, $p$ and $q$, depend on the level of domestic financial development $\beta$. The constraint $a \geq 0$ is binding if and only if the marginal return on capital is larger than the marginal return on reserves when there is zero reserves, i.e.

$$
f^{\prime}(k) \geq 1-\pi+\frac{\pi}{q(k, 0)} .
$$

The left-hand side and right-hand side of this inequality are respectively decreasing and increasing in $k$. Thus (26) is satisfied if and only if $k$ is lower than the level $\widehat{k}$ for which it is an equality. The threshold $\widehat{k}$ is between $\phi$ and $k^{L F}$ because $k=\phi$ satisfies (26) but $k^{L F}$ does not. ${ }^{10}$

Having defined $\widehat{k}$, we can distinguish between three stages of financial development.

1. Low financial development. For $\beta \leq \widehat{k}$, EM agents borrow $\beta$ and invests the proceeds in illiquid domestic capital: $k=\beta$ and $a=0$. Constraint (25) is binding because $\beta$ is lower than $k^{L F}+a^{L F}$ and EM agents do not invest in reserves because (26) is satisfied.

2. Intermediate financial development. For $\beta \in\left[\widehat{k}, k^{L F}+a^{L F}\right]$, constraint (25) is still binding, but EM borrowers now invest a share of capital inflows in reserves. The comparative statics of capital flows with respect to changes in financial development are stated in the following proposition.

cient lower than one. The r.h.s. is the amount of good that foreign creditors can recover in a default. If this constraint were violated, the borrower could make a take-or-leave offer to reduce her debt to that amount in period 0 , which the creditors would accept. Using (1) to substitute out $a+k$, this credit constraint can be rewritten as (25) with $\beta=\alpha /(1-\gamma)$.

${ }^{10}$ For $k=\phi$ this is an implication of $q(\phi, 0)=1$ and $\phi<k^{F B}$. For $k=k^{L F}$ note that since $a^{L F}>0, f^{\prime}\left(k^{L F}\right)=1-\pi+\pi / q\left(k^{L F}, a^{L F}\right)<1-\pi+\pi / q\left(k^{L F}, 0\right)$. 
Proposition 4 (Impact of financial development on capital flows) EM borrowers hold a positive level of reserves and their external borrowing is constrained if and only if the level of domestic financial development is intermediate, $\beta \in\left[\widehat{k}, k^{L F}+a^{L F}\right]$. In this case domestic financial development (an increase in $\beta$ ) raises physical investment $k$ and reserves $a$ as well as the price of EM debt,

$$
\frac{\partial k}{\partial \beta}>0, \frac{\partial a}{\partial \beta}>0 \text { and } \frac{\partial p}{\partial \beta}>0 .
$$

Proof. In equilibrium $k$ and $a$ satisfy

$$
\begin{aligned}
k+a & =\beta, \\
f^{\prime}(k) & =1-\pi+\frac{\pi}{q(k, a)} .
\end{aligned}
$$

The first equation is the budget constraint (1) using the fact that (25) is binding. The second equation equates the marginal product of capital and the marginal benefit of reserves. These two equations can be represented by respectively a downward-sloping locus and upward-sloping locus in the space $(k, a)$. An increase in $\beta$ shifts the downward-sloping locus up and so increases both $k$ and $a$. Using the second equation, an increase in $k$ implies an increase in $q$ and so in $p$.

Financial development leads to gross capital inflows that finance increments in both physical capital and foreign reserves. Both capital and reserves increase at the margin because domestic agents equate the returns on both types of assets. The return on reserves falls because the fire-sale price of EM debt increases with the level of reserves.

3. High financial development. For $\beta>k^{L F}+a^{L F}$, constraint (25) is no longer binding so that further financial development does not affect capital flows.

Figure 4 illustrates the impact of financial development on the main endogenous variables. ${ }^{11}$ The left-hand side and right-hand panels respectively

\footnotetext{
${ }^{11}$ We use the following model specification and calibration: $f(k)=2 \sqrt{k}, \phi=0.5$, $\pi=0.1$ and $R=1.2$. The numerical illustrations presented in the rest of the paper will be based on the same parameter values.
} 
show the impact of financial development on gross capital flows and the price of EM debt. For $\beta<\widehat{k}$, the capital inflows allowed by financial development finance only physical capital and no reserves are accumulated. If $\beta<\phi$, larger debt inflows do not reduce the price of debt because foreign arbitrageurs have enough resources to buy back all the debt in a sudden stop. When $\beta>\phi$ the price of debt initially falls sharply with the level of borrowing as capital inflows do not finance the accumulation of reserves. The response of the debt price to gross inflows is reversed when $\beta>\widehat{k}$. The capital inflows allowed by financial development then finance mostly the accumulation of foreign reserves, which raises the price of EM debt.
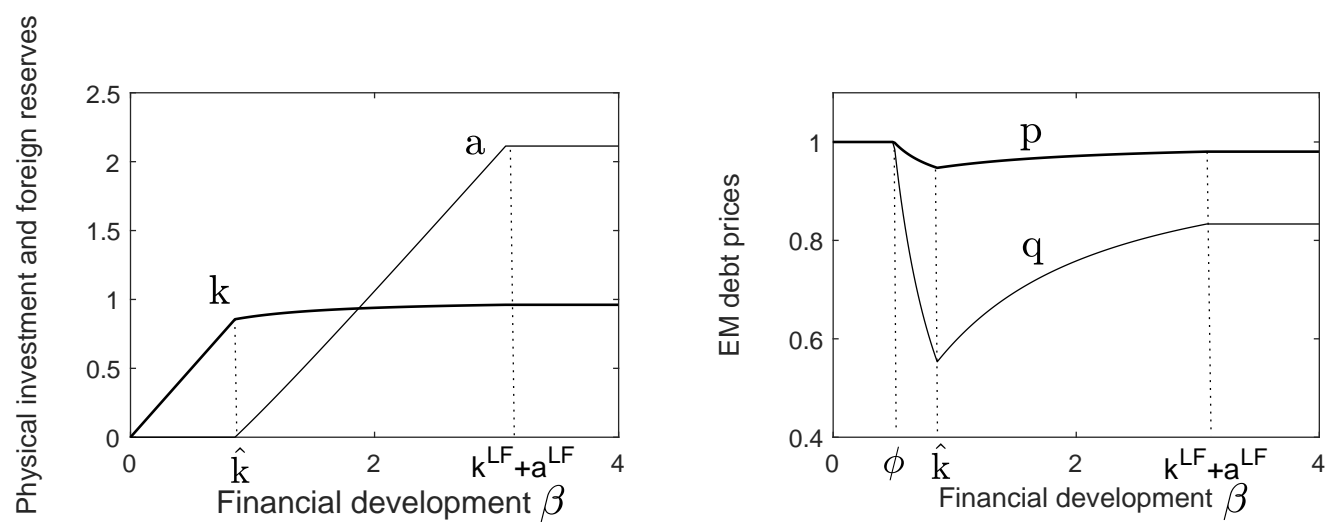

Figure 4: Financial development and capital flows

\section{Policies}

We now turn to optimal public interventions. Section 5.1 characterizes the externalities that justify the intervention of a social planner and solves for the social planner allocation. Section 5.2 looks at the role of open market operations by the government that can be interpreted as sterilized foreign exchange interventions.

\subsection{Externalities}

We now consider a constrained-efficient social planner, who sets $a$ and $b$ in period 0 so as to maximize the welfare of EM borrowers subject to the 
same constraints as private agents. The wedge between the private and social impacts of changing the EM balance sheet comes from a pecuniary externality. The social planner takes into account the impact of changing the EM representative agent's balance sheet on the debt prices $p$ and $p^{\prime}$ whereas private borrowers do not. In the spirit of macroprudential policy we assume that the social planner intervenes only ex ante (in period 0) and leave for later a discussion of ex post (period 1) interventions.

The social planner can manipulate the EM debt price exploiting the fact that the EM country is a monopolist in the market for its own debt. Which way the social planner wants to move prices is not clear a priori because EM agents are both sellers and buyers in the market for EM debt. In period 0 EM agents sell debt and benefit from a higher price $p$. In a sudden stop the same agents buy back debt and benefit from a lower price $q$. Since $p$ and $q$ are related by (10) the social planner must trade off the two benefits.

Social vs. private value of liquidity. We use (10) and (17) to write EM welfare as

$$
U_{0}^{E M}=f(k)-\frac{k+a}{(1-\pi+\pi R q) / R^{e}}+a\left(1-\pi+\frac{\pi}{q}\right) .
$$

Decentralized agents take $q$ as given but the EM social planner takes into account that $q$ is endogenous to $k$ and $a$. The difference between the social value and the private value of liquidity is

$$
\frac{\partial U_{0}^{E M}}{\partial q} \frac{\partial q}{\partial a}
$$

where the partial derivative of $U_{0}^{E M}$ is taken for constant $k$ and $a$ in (27).

Proposition 5 (Social value of liquidity) The social value of liquidity is higher than the private value of liquidity under laissez-faire.

Proof. Since $\partial q / \partial a>0$ we need to prove that $\partial U_{0}^{E M} / \partial q>0$. We have

$$
\begin{aligned}
\frac{\partial U_{0}^{E M}}{\partial q} & =\frac{\partial}{\partial q}\left(-\frac{R^{e}(k+a)}{1-\pi+\pi R q}+a \frac{\pi}{q}\right) \\
& =\frac{\pi}{p^{2}}\left[\frac{R}{R^{e}}(k+a)-a\left(\frac{p}{q}\right)^{2}\right], \\
& =\pi \phi R^{2}>0,
\end{aligned}
$$


where we have used the fact that in the laissez-faire equilibrium, $p=1 / R^{e}$, $q=1 / R, k=k^{L F}$ and $a=a^{L F}$ given by (24).

The laissez-faire equilibrium involves an under-accumulation of liquidity. EM welfare is increased by larger capital inflows that finance additional reserves. This result runs counter to the idea that gross capital flows are excessively large and volatile under laissez-faire. The problem is actually the opposite: gross flows are not large enough in the decentralized equilibrium. Gross capital flows play a stabilizing role in our model because they stabilize the price of domestic debt ex post (in period 1) and thus reduce the risk premium that the country has to pay ex ante (in period 0 ).

The intuition behind this result can be better understood by looking at global welfare. Global welfare is the sum of the welfare of EM residents, foreign bankers and foreign arbitrageurs, ${ }^{12}$

$$
U_{0}^{W}=U_{0}^{E M}+U_{0}^{B}+U_{0}^{A}
$$

where the welfare of the three types of agents is given by,

$$
\begin{aligned}
U_{0}^{E M} & =f(k)-b+a\left(1-\pi+\frac{\pi}{q}\right), \\
U_{0}^{B} & =R \kappa, \\
U_{0}^{A} & =E_{0}\left(c^{A}\right)=\phi\left(1-\pi+\frac{\pi}{q}\right) .
\end{aligned}
$$

These expressions come from equations (9), (10), (6), (16) and using the fact that $p^{\prime}$ is equal to 1 with probability $1-\pi$ and to $q$ with probability $\pi$. Observe that the welfare of bankers is independent of the EM country's balance sheet and is equal to the payoff on their unliquidated legacy asset. Summing up (29), (30) and (31) and using $q=(a+\phi) / b$ we have,

$$
U_{0}^{W}=R \kappa+f(k)-(1-\pi)(b-a-\phi) .
$$

Then using (10) and $q=(a+\phi) / b$ to substitute out $p$ from (1) gives $(1-\pi)(b-a-\phi)=R^{e}(k-\phi)$ so that the expression above can be rewritten,

$$
U_{0}^{W}=R \kappa+R^{e} \phi+f(k)-R^{e} k .
$$

\footnotetext{
${ }^{12} \mathrm{We}$ do not include the welfare of the foreign investors who are not bankers or arbitrageurs, which is simply equal to their endowments.
} 
Global welfare is equal to the payoff on the bankers' unliquidated legacy asset, plus the value of the foreign arbitrageurs' endowment invested at $R^{e}$, plus the EM investment surplus assuming a cost of funds of $R^{e}$. Importantly, global welfare is constant given $k$. For a given level of physical investment, changes in the EM balance sheet only redistribute welfare between EM agents and foreign arbitrageurs.

Using (32) one can rewrite EM welfare as,

$$
U_{0}^{E M}=U_{0}^{W}-U_{0}^{A}-U_{0}^{B}=f(k)-R^{e} k+\pi \phi\left(R-\frac{1}{q}\right) .
$$

Given $k$, EM welfare is increasing in $q$. The EM social planner thus always finds it optimal to increase $q$, which can be done by raising the level of capital inflows and reserves. The social planner allocation is characterized in the following proposition.

Proposition 6 (Social planner allocation) Assume that the social planner maximizes EM welfare subject to $b p \leq \beta$. The social planner maximizes the volume of capital inflows, i.e., bp $\leq \beta$ is binding. In the social planner allocation the level of reserves is higher, and the level of physical capital lower, than under laissez-faire: $a^{S P}>a^{L F}$ and $k^{S P}<k^{L F}$.

Proof. The Lagrangian for the social planner's problem is,

$$
U_{0}^{E M}=f(k)-R^{e} k+\pi \phi\left(R-\frac{1}{q(k, a)}\right)+\lambda(\beta-k-a) .
$$

The first-order condition for $a$ is

$$
\lambda=\frac{\pi \phi}{q^{2}} \frac{\partial q}{\partial a}>0
$$

which implies that constraint $b p \leq \beta$ is binding.

The first-order condition for $k$ is

$$
f^{\prime}(k)=R^{e}-\frac{\pi \phi}{q^{2}} \frac{\partial q}{\partial k}+\lambda .
$$

Since $\partial q / \partial k<0$, one has $f^{\prime}(k)>R^{e}$ which implies $k^{S P}<k^{L F}$.

This proposition is a stronger version of Proposition 5. Not only does the social planner want to marginally increase the level of gross capital inflows under laissez-faire, she wants to maximize the level of capital inflows. 
By doing so the EM social planner transfers some of the rent that foreign arbitrageurs extract from the fire sale of EM debt to her own residents.

The social planner lowers the ex-ante cost of borrowing for private agents closer to the first-best level. At the same time, she does not raise $k$-instead she decreases it below the laissez-faire level. This is because the social planner's intervention does not decrease the social cost of borrowing taking into account the lower profit on reserves. Like private agents, the social planner is constrained by the fact that external finance comes from leveraged bankers who demand a compensation for the risk of having to liquidate legacy assets. Hence the social planner, rather than increasing $k$, lowers it to accumulate a little more liquidity at the margin.

Remark 1. Implementation with Pigouvian taxes. A priori the social planner allocation can be implemented with two policy instruments since the social planner has two target $(k$ and $a)$. We consider the case where the social planner can use taxes on reserves and capital accumulation, respectively denoted by $\tau_{a}$ and $\tau_{k}$. The period-0 budget constraint of EM agents becomes

$$
\left(1+\tau_{k}\right) k+\left(1+\tau_{a}\right) a=p b+z,
$$

where $z$ is the lump-sum rebate of the taxes.

The optimal taxes are characterized in Appendix A1 and we summarize the main results here. The levels of the optimal taxes are not uniquely determined because the constraint $k+a \leq \beta$ is binding. The social planner allocation can thus be implemented with only one instrument, a subsidy on reserves. If the constraint $k+a \leq \beta$ is binding under laissez-faire, the subsidy induces EM agents to invest less in $k$ and more in $a$. If the constraint $k+a \leq \beta$ is not binding under laissez-faire, the subsidy induces EM agents to borrow more.

Remark 2. Ex post interventions. We have assumed that the social planner does not intervene in period 1, and in particular lets private agents spend all their reserves in a sudden stop. We show in Appendix A2 that this is not time consistent: ex post, the social planner may want to curtail the sales of private reserves in order to maximize the country's rent from the fire sale. The social planner allocation described in Proposition 6, thus, requires a credible commitment to let private agents use all their reserves in period 1.

Remark 3. Welfare criterion. No Pareto improvement benefiting 
both EM agents and foreign investors is possible starting from laissez-faire. Any Pareto improvement would have to increase global welfare, but global welfare is already at its maximum level under laissez-faire since (32) is maximized for $f^{\prime}(k)=R^{e}$. A global social planner applying the Pareto criterion, thus, would not alter the laissez-faire allocation.

It is unclear, however, that the Pareto criterion is an appropriate one in the context of this model. The Pareto criterion implies the preservation of the rent of foreign arbitrageurs, even though this rent is paid by the EM economy which is a victim of the financial friction affecting foreign banks. The EM social planner allocation brings the global economy closer to the first-best welfare allocation, under which foreign arbitrageurs do not appropriate any rent.

Policy international could also be motivated by concerns about inequality. Because of linearity in agents' utility, the model does not take into account the possible income inequality between EM borrowers and foreign arbitrageurs. Redistributing income from richer foreign arbitrageurs to poorer EM borrowers would increase total welfare if utility were concave. One may capture this idea by assuming that the social planner puts a lower weight $1-\omega$ on the welfare of foreign arbitrageurs than on the welfare of EM residents. The objective function of the global social planner would then be

$$
\begin{aligned}
U_{0}^{G S P} & =U_{0}^{E M}+(1-\omega) U_{0}^{A}, \\
& =f(k)-R^{e} k-+R^{e} \phi-\omega \phi\left(1-\pi+\frac{\pi}{q(k, a)}\right) .
\end{aligned}
$$

If $\omega$ is close to 0 (i.e. the social planner values the welfare of foreign arbitrageurs almost as much as that of EM borrowers), the global social planner implements a level of physical investment that is about the same as under laissez-faire but also maximizes the level of EM external borrowing in the same way as the EM social planner. Therefore, the conclusion that gross capital flows should be increased above the laissez-faire carries over to the global social planner under the fairly weak assumption that it puts more weight on the welfare of EM borrowers, even by a vanishingly small amount.

\subsection{Government reserves}

We now introduce an EM government that can borrow and accumulate reserves. The government has no real expenditure. The budget constraints of 
the government are

$$
\begin{aligned}
a^{g} & =p b^{g}, \\
a^{g}+p^{\prime} b^{\prime g} & =a^{\prime g}+p^{\prime} b^{g}, \\
b^{\prime g}+z & =a^{\prime g}
\end{aligned}
$$

where $z$ is a lump-sum transfer to the private sector. The budget constraints (1)-(3) still apply to the EM agents, with the transfer $z$ added to the period-2 budget constraint.

We assume that the government sells all its reserves to buy back EM debt if there is a sudden stop in period 1 . That is, $a^{g}=0$ and $z=(1 / q-1 / p) a^{g}>$ 0 in the event of a sudden stop. Note that when it intervenes the government purchases more debt that it has issued in period $0\left(b^{\prime g}<0\right)$. The government does not intervene if external financial conditions are normal: $a^{g}=a^{g}$ and $z=-(1 / p-1) a^{g}<0$ (the government imposes a tax $-z$ to pay for the carry cost of reserves).

We interpret these government balance sheet operations as sterilized foreign exchange interventions by the central bank. When the central bank buys foreign reserves and sells the same quantity of domestic government debt, it increases the total supply of debt by the consolidated government sector (treasury plus central bank) to the private sector and accumulates an equivalent quantity of reserves. This corresponds to an increase in $b^{g}$ and $a^{g}$ in our model.

We assume that the government has its own borrowing constraint in period 0 ,

$$
p b^{g} \leq \beta^{g} .
$$

The borrowing constraints of the government and the private sector are separate because they are determined by different factors. The borrowing constraint of private borrowers is determined by private creditor rights and their enforcement. The borrowing constraint of the government is determined by its ability to raise taxes and the cost of defaulting on government debt.

Note that we have imposed constraints on what the government can do with its balance sheet. Most importantly, the government cannot make transfers to the private sector in period 0 . Otherwise, the government could use its borrowing capacity to finance more investment in physical capital in period 0 . It is easy to see (by consolidating the budget constraint of the government with that of the private sector) that in this case, the government could 
achieve the same allocations as in the laissez-faire equilibrium in which the private sector borrowing capacity is increased from $\beta$ to $\beta+\beta^{g}$. That is, the effect of government balance sheet interventions would be equivalent to that of financial development. This is not the case here because we do not allow the government to make such transfers in period 0 , our focus being on reserves interventions.

We then have the following result.

Proposition 7 (Government reserves interventions) Government reserves interventions are welfare-increasing if and only if the level of domestic financial development $\beta$ is in the interval, $\beta \in\left(\phi, k^{L F}+a^{L F}\right)$. If the private sector holds reserves, a government accumulation of reserves partially crowds out private reserves, crowds in physical investment and raises the price of government debt,

$$
-1<\frac{\partial a}{\partial \beta^{g}}<0, \frac{\partial k}{\partial \beta^{g}}>0, \frac{\partial p}{\partial \beta^{g}}>0
$$

Proof. If $\beta \leq \phi, p$ and $q$ are equal to 1 so that the government does not change welfare with reserves interventions. If $\beta \geq k^{L F}+a^{L F}$, the economy is in a Ricardian regime in which government reserves interventions have no impact because they are offset by the private sector (as long as they are small enough to leave private reserves strictly above zero, which is true if $\beta^{g}<a^{L F}$ ). Thus, government reserves interventions can be welfare-increasing only if $\beta \in\left(\phi, k^{L F}+a^{L F}\right)$.

Government reserves interventions are indeed welfare-increasing if $\beta$ is in this interval. If the private sector does not accumulate reserves under laissez-faire $(k=\beta)$, a marginal accumulation of government reserves does not change $k$ but raises $q$, which increases welfare by (33). If the private sector accumulates reserves under laissez-faire $(k<\beta$ and $a>0)$, a marginal accumulation of government reserves is equivalent to a marginal increase in financial development under laissez-faire, which raises welfare. This increase total reserves, physical capital, and the price of EM debt as shown in Proposition 4.

The impact of government reserves interventions depends on the level of financial development. If financial development is low the country does not issue enough debt to be affected by a sudden stop and there is no strict benefit from reserves interventions. If financial development is high, the 
economy is in a Ricardian regime where government reserves interventions have no impact. Thus, government reserves interventions raises welfare only for intermediate levels of financial development.

The left-hand side panel of Figure 5 shows the optimal level of public reserves. ${ }^{13}$ There is a discontinuity at $\beta=\phi$, where the optimal level of reserves jumps up from zero to $\beta^{g}$. As soon as the EM economy is affected by a sudden stop the government should accumulate as much reserves as possible. For $\beta>k^{L F}+a^{L F}$ the government cannot affect total reserves because of Ricardian equivalence and thus stops accumulating reserves. For $\beta$ smaller than but close to $k^{L F}+a^{L F}$, the government accumulates just enough reserves to fill the gap between $\beta$ and $k^{L F}+a^{L F}$.

The right-hand side panel of Figure 5 compares the welfare gains from the optimal reserves interventions discussed in this section with the optimal reserves subsidy discussed in the previous section. For intermediate levels of financial development the welfare gains are substantially larger for reserves interventions than for the reserves subsidy because reserves interventions relax constraint (25) whereas reserves subsidies keep this constraint unchanged. In other terms, the welfare gains from reserves interventions are significantly larger than the gains from capital controls for countries at intermediate levels of financial development.
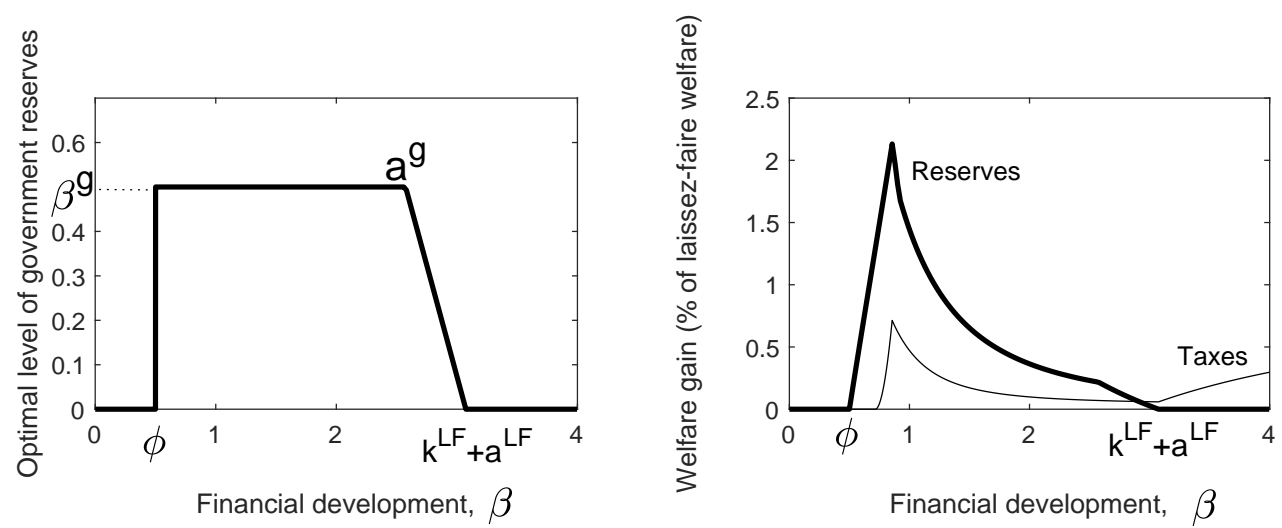

Figure 5: Optimal reserves interventions

\footnotetext{
${ }^{13}$ We use the same parameter values to construct Figure 4 and set $\beta^{g}=0.5$. We set the optimal level of reserves to zero when reserves interventions do not affect welfare.
} 


\section{Evidence}

The model makes predictions about how EMs are affected by, and respond to, the global financial cycle depending on the level of financial development. EMs smooth the impact of the global financial cycle with their external balance sheets that pulsate to the rhythm of the global financial cycle: when global financial conditions are loose, EMs absorb large inflows with which they finance large outflows, and unwind these positions when global financial conditions tighten. EMs that are more financially developed and can build up larger external balance sheets, experience larger, more volatile, but also more correlated inflows and outflows. The offsetting behavior of gross capital flows stabilizes the price of domestic assets allowing more financially developed EMs to finance themselves externally on better terms on average. Foreign exchange intervention can enhance this adjustment mechanism but its role is increasingly fulfilled by private sector reserves as the country's level of financial development and integration increases.

These facts are broadly consistent with the behavior of capital flows in EMs - especially during the 2008-09 global financial retrenchment as shown by Figure 1 -and with the literature on the global financial cycle. In this section, we investigate the extent to which the cross-country evidence is consistent with the model predictions. The purpose of this section is to provide suggestive evidence consistent with the model rather than to formally test the model against possible alternatives.

Data. We first describe the country sample and the data. Our baseline empirical analysis uses annual data and focuses on a core sample of EMs that belong to the MSCI Emerging Market Index and have at least 10 years of data. We use data from the IMF International Investment Position (IIP) and Balance of Payments (BOP) statistics from 1990 to 2017. IIP statistics include data on the stock of foreign assets and liabilities, while BOP data provide information on gross capital flows and the investment income from gross liabilities and assets. The list of countries is reported in appendix B.

We assess the robustness of our empirical findings along several dimensions. First, we consider a larger sample of EMs which includes all countries at an intermediate level of development. ${ }^{14}$ Second, we replicate the analysis

\footnotetext{
${ }^{14}$ This larger sample includes all countries with population above 2 million, except those considered as "Advanced Economies" by the IMF World Economic Outlook or as "Low Income" by the World Bank.
} 
by considering only countries with complete data from 2005 onward. This ensures that our findings are not driven by the unbalanced nature of the dataset since the time-series coverage varies significantly across countries especially before 2005 . Third, we check whether the results are robust to using quarterly data, considering countries with at least 5 years of data. Quarterly data are generally available for a shorter time span but for several countries they provide more data points given the higher frequency of observation.

The model makes predictions about the returns on foreign assets and liabilities. Using BOP and IIP data, we compute for each country and period $t$ the rate of return on foreign assets $r_{t}^{A}$ and liabilities $r_{t}^{L}$ as follows:

$$
\begin{aligned}
r_{t}^{A} & =\left(A_{t}-O_{t}+Y_{t}^{A}\right) / A_{t-1}-1 \\
r_{t}^{L} & =\left(L_{t}-I_{t}+Y_{t}^{L}\right) / L_{t-1}-1
\end{aligned}
$$

where $A_{t}$ and $L_{t}$ denote assets and liabilities, $O_{t}$ and $I_{t}$ are gross outflows and inflows, and $Y_{t}^{A}$ and $Y_{t}^{L}$ are the income payments on assets and liabilities. We define a country's international borrowing spread as the difference between the return paid on liabilities and the return earned on assets, $r_{t}^{L}-r_{t}^{A}$, as for example in Gourinchas and Rey (2007) and Lane and Milesi-Ferretti (2007).

We compare three predictions of the model with the data.

Prediction 1: gross capital inflows are positively correlated with gross capital outflows and with the borrowing spread over time. In the model, capital inflows are correlated with capital outflows for countries that accumulate (private or public) reserves. Period 0 can be viewed as a capital flow boom (with large and positive inflows and outflows) whereas period 1 features a retrenchment (with negative inflows and outflows) if external financial conditions tighten. Furthermore, the price of the domestic asset falls if there is a retrenchment, leading to a low return for foreign investors. Domestic investors receive a zero return on their reserves. This implies that a retrenchment is correlated with a low realized borrowing spread in period 1 of the model. More generally, gross inflows and outflows tend to expand when EM asset prices are increasing and viceversa, implying a positive correlation between gross flows and the borrowing spread.

Table 1 reports these correlations in our sample of analysis. For each country, we compute the time-series correlation between inflows and outflows and report the cross-country average in the first row of the table. The average correlation is positive and statistically significant across all EM samples and 
data frequencies. This is consistent with a number of findings reported in the literature, e.g. Forbes and Warnock (2012), Broner et al. (2013), IMF (2013), and Davis and van Wincoop (2017).

Table 1: Correlation of capital flows and international borrowing spreads

\begin{tabular}{|c|c|c|c|c|c|c|}
\hline & (1) & (2) & (3) & (4) & (5) & (6) \\
\hline & \multicolumn{3}{|c|}{ Annual data } & \multicolumn{3}{|c|}{ Quarterly data } \\
\hline & \multirow{2}{*}{$\begin{array}{c}\text { Core EM } \\
\text { sample }\end{array}$} & \multicolumn{2}{|c|}{ Large EM sample } & \multirow{2}{*}{$\begin{array}{c}\text { Core EM } \\
\text { sample }\end{array}$} & \multicolumn{2}{|c|}{ Large EM sample } \\
\hline & & all years & post 2005 & & all years & post 2005 \\
\hline \multicolumn{7}{|l|}{ Correlation: } \\
\hline Inflows/outflows & $0.69 * * *$ & $0.44 * * *$ & $0.53 * * *$ & $0.77 * * *$ & $0.61 * * *$ & $0.69 * * *$ \\
\hline Inflows/spreads & $0.12 * *$ & $0.09 * *$ & $0.10 *$ & $0.16^{* * *}$ & 0.04 & $0.12 *$ \\
\hline Outflows/spreads & $0.26^{* * *}$ & $0.22 * * *$ & $0.25 * * *$ & $0.23 * * *$ & $0.17 * * *$ & $0.18 * *$ \\
\hline
\end{tabular}

The more novel prediction of the model is the positive correlation between gross flows and the borrowing spread. The second and third rows of Table 1 confirm that gross flows are positively correlated with borrowing spreads, i.e. with the excess return on EM assets relative to foreign assets. In other words, when EM asset prices are booming, thus generating a higher realized borrowing spread, foreigners tend to buy EM assets while residents invest abroad. The opposite dynamic takes place when EM asset prices decline. This suggests that EM residents seize a trading advantage by selling domestic assets to foreigners when prices are high and buying them back at a discount when prices are low. ${ }^{15}$

Prediction 2: the borrowing spread is negatively correlated with the size of external liabilities across countries. This is perhaps the most counterintuitive implication of the model. Conventional wisdom suggests that countries with larger foreign liabilities are more exposed to changes in the global financial cycle. This could imply greater instability and higher international borrowing spreads, as foreign investors demand higher risk premia. As shown in section 4, however, the model predicts that domestic financial development leads to both a larger stock of foreign liabilities and a lower cost of borrowing abroad. Formally, the borrowing spread in the model

\footnotetext{
${ }^{15}$ In line with our findings, Caballero and Simsek (2020) show that in 30 OECD countries gross capital flows tend to decline when expected stock returns increase.
} 
is measured by $1 / p-1$, i.e., the spread between the long-term interest rate at which the country borrows abroad and the (zero) return on foreign assets. An increase in external liabilities leads to an increase in $p$ (see Proposition 4) and so to a decrease in the borrowing spread.

The model prediction is in line with the evidence presented in Table 2. The table shows that countries with larger gross liabilities in percent of GDP tend to enjoy lower international borrowing spreads. This is true across all country samples and data frequency. This effect is economically significant. Looking at the results based on annual data, an increase in gross liabilities of 10 percent of GDP is correlated with a 50 basis points reduction in borrowing spreads.

Table 2: International borrowing spreads over size of foreign liabilities

\begin{tabular}{|c|c|c|c|c|c|c|}
\hline & (1) & (2) & (3) & (4) & (5) & (6) \\
\hline & \multicolumn{3}{|c|}{ Annual data } & \multicolumn{3}{|c|}{ Quarterly data } \\
\hline & \multirow{2}{*}{$\begin{array}{c}\text { Core EM } \\
\text { sample }\end{array}$} & \multicolumn{2}{|c|}{ Large EM sample } & \multirow{2}{*}{$\begin{array}{c}\text { Core EM } \\
\text { sample }\end{array}$} & \multicolumn{2}{|c|}{ Large EM sample } \\
\hline & & all years & post 2005 & & all years & post 2005 \\
\hline Liabilities & $\begin{array}{c}-0.04 * * \\
(0.02)\end{array}$ & $\begin{array}{c}-0.06 * * * \\
(0.02)\end{array}$ & $\begin{array}{c}-0.05 * * * \\
(0.02)\end{array}$ & $\begin{array}{c}-0.11 * * \\
(0.04)\end{array}$ & $\begin{array}{l}-0.04 * \\
(0.02)\end{array}$ & $\begin{array}{c}-0.23 * * * \\
(0.04)\end{array}$ \\
\hline Constant & $\begin{array}{c}7.62 * * * \\
(1.77)\end{array}$ & $\begin{array}{c}9.88 * * * \\
(1.71)\end{array}$ & $\begin{array}{c}9.18^{* * *} \\
(1.55)\end{array}$ & $\begin{array}{c}13.99 * * * \\
(4.01)\end{array}$ & $\begin{array}{c}7.61 * * * \\
(2.46)\end{array}$ & $\begin{array}{c}24.78 * * * \\
(4.47)\end{array}$ \\
\hline Countries & 22 & 61 & 47 & 16 & 40 & 14 \\
\hline R-squared & 0.18 & 0.16 & 0.21 & 0.38 & 0.09 & 0.767 \\
\hline
\end{tabular}

A possible concern with the interpretation of our results is that spreads may decline in countries that have larger foreign liabilities because they are intrinsically safer and less susceptible to fleeing foreign investors. Columns (1) to (3) in Table 3 shows that this is not the case, since capital inflows are more volatile in countries with larger liabilities. As shown in columns (4) to (6), the decline in borrowing spreads is correlated with the higher covariance between gross inflows and outflows in countries with larger liabilities, which is consistent with the model.

Prediction 3: the use of foreign exchange interventions is negatively correlated with the size of foreign liabilities across countries. As we showed in section 4, financial development allows the private sector to accumulate its own reserves, reducing the need for the government to stabilize 
Table 3: Variance and covariance of capital flows over foreign liabilities

\begin{tabular}{|c|c|c|c|c|c|c|}
\hline & (1) & (2) & (3) & (4) & (5) & (6) \\
\hline & \multicolumn{3}{|c|}{ Variance of capital inflows } & \multicolumn{3}{|c|}{ Covariance inflows/outflows } \\
\hline & \multirow{2}{*}{$\begin{array}{c}\text { Core EM } \\
\text { sample }\end{array}$} & \multicolumn{2}{|c|}{ Larger EM sample } & \multirow{2}{*}{$\begin{array}{c}\text { Core EM } \\
\text { sample }\end{array}$} & \multicolumn{2}{|c|}{ Larger EM sample } \\
\hline & & all years & post 2005 & & all years & post 2005 \\
\hline \multirow[t]{2}{*}{ Liabilities } & $0.09 * * *$ & $0.07 * * *$ & $0.08 * * *$ & $1.73 * * *$ & $0.89 * * *$ & $1.53 * * *$ \\
\hline & $(0.01)$ & $(0.01)$ & $(0.01)$ & $(0.26)$ & $(0.15)$ & $(0.24)$ \\
\hline \multirow[t]{2}{*}{ Constant } & $-2.44 * *$ & -0.47 & -1.38 & $-103.81 * * *$ & $-53.79 * * *$ & $-104.03 * * *$ \\
\hline & $(0.93)$ & $(0.72)$ & $(0.91)$ & $(23.50)$ & $(14.43)$ & $(24.78)$ \\
\hline Countries & 22 & 61 & 47 & 22 & 61 & 47 \\
\hline R-squared & 0.80 & 0.56 & 0.62 & 0.69 & 0.37 & 0.47 \\
\hline
\end{tabular}

domestic asset prices with foreign exchange interventions. Foreign exchange interventions also become less effective because of Ricardian equivalence.

Indeed, columns (1) to (3) in Table 4 show that countries with larger liabilities tend to have a lower share of reserves in foreign assets. Furthermore, besides holding relatively fewer reserves, these countries use them less actively in offsetting inflows. Columns (4) to (6) show indeed that countries with larger liabilities have a lower covariance between reserves and gross inflows relative to the covariance between outflows and inflows. This implies that the private sector plays a more preponderant role in offsetting movements in capital inflows as financial development deepens.

\section{Conclusions}

The global financial cycle exposes emerging markets to large fluctuations in capital inflows. A common policy prescription is to increase resilience by restricting capital flows, for example through the use of capital controls. In this paper, we offered a different perspective by pointing out that countries can buffer the volatility of capital inflows with offsetting capital outflows. We formalized this argument using a tractable model which shows that emerging markets can use their balance sheets to manage the ebb and flow of the global financial cycle. This requires accumulating reserves when capital inflows are high, and using them to buy back domestic assets at lower prices when foreign investors disinvest. To fully benefit from this buffering mechanism, countries 
Table 4: Size and use of official reserves over foreign liabilities

\begin{tabular}{|c|c|c|c|c|c|c|}
\hline & (1) & (2) & (3) & (4) & $(5)$ & (6) \\
\hline & \multicolumn{3}{|c|}{ Share of reserves in foreign assets } & \multicolumn{3}{|c|}{$\operatorname{cov}($ reserves,infl.) / cov(outflows,infl.) } \\
\hline & \multirow{2}{*}{$\begin{array}{c}\text { Core EM } \\
\text { sample }\end{array}$} & \multicolumn{2}{|c|}{ Larger EM sample } & \multirow{2}{*}{$\begin{array}{c}\text { Core EM } \\
\text { sample }\end{array}$} & \multicolumn{2}{|c|}{ Larger EM sample } \\
\hline & & all years & post 2005 & & all years & post 2005 \\
\hline \multirow[t]{2}{*}{ Liabilities } & $-0.22 * * *$ & $-0.12 * *$ & $-0.16 * * *$ & $-0.35 * *$ & $-0.36 * *$ & $-0.30 * * *$ \\
\hline & $(0.08)$ & $(0.05)$ & $(0.05)$ & $(0.16)$ & $(0.15)$ & $(0.10)$ \\
\hline \multirow[t]{2}{*}{ Constant } & $59.11 * * *$ & $54.57 * * *$ & $58.29 * * *$ & $77.14 * * *$ & $91.84 * * *$ & $82.57 * * *$ \\
\hline & $(6.82)$ & $(5.00)$ & $(5.47)$ & $(14.98)$ & $(14.61)$ & $(10.89)$ \\
\hline Countries & 22 & 61 & 47 & 21 & 44 & 38 \\
\hline R-squared & 0.29 & 0.09 & 0.17 & 0.20 & 0.12 & 0.20 \\
\hline
\end{tabular}

need to be sufficiently financially developed to buildup large external balance sheets.

The model also revealed that the private sector tends to under-invest in liquidity since it does not internalize how the country's balance sheet affects asset prices. A social planner would thus increase the size of gross capital flows beyond the laissez-faire equilibrium rather than restrict capital flows in line with conventional policy prescription. This exposes the country to higher volatility in gross flows but leads to more stable domestic asset prices, reducing the risk premium on international borrowing. The social planner's solution can be implemented with a subsidy on the accumulation of foreign reserves by the private sector.

In countries at a relatively low level of financial development-where financial constraints limit the issuance of international debt by private agentsthe government can use its own balance sheet to manage the global financial cycle. By accumulating official reserves when global conditions are loose and selling them when conditions are tight, the government can complement the buffering role provided by the private sector. As financial development progresses, foreign exchange intervention becomes less helpful since the private sector can insure itself to a large extent. The model implications are in line with empirical stylized facts showing that more financially developed countries tend to have greater covariance between inflows and outflows, benefit from lower borrowing spreads, and rely less on official reserves.

In the paper, we used a stylized three-period model to clarify the key 
mechanisms behind financial buffering. The analysis can be extended in several directions. First, by introducing non-tradable goods, the model can be used to examine whether and how financial buffering can also help to stabilize the real exchange rate. Second, the model can be nested into a conventional DSGE framework to analyze its quantitative implications. 


\section{A Model Appendix}

\section{A.1 Pigouvian taxes}

Social planner allocation. As shown in the proof of Proposition 6, the first-order condition for the social planner maximizing EM welfare subject to $(25)$ is

$$
f^{\prime}(k)=R^{e}+\frac{\pi \phi}{q^{2}}\left(\frac{\partial q}{\partial a}-\frac{\partial q}{\partial k}\right) .
$$

Using (12) and the binding constraint $k+a=\beta$ this condition can be rewritten as

$$
f^{\prime}(k)=R^{e}\left[1+\frac{\pi}{1-\pi} \frac{\phi \beta}{(a+\phi)^{2}}\right] .
$$

This condition, together with $k+a=\beta$, determine the social planner allocation $k^{S P}, a^{S P}$. Both $k^{S P}$ and $a^{S P}$ are increasing in $\beta$.

Taxes on capital and reserves. With the Pigouvian taxes in equation (34) the welfare of the EM representative resident is

$$
\begin{aligned}
U_{0}^{E M} & =f(k)-b+a E\left(\frac{1}{p^{\prime}}\right) \\
& =f(k)-\frac{\left(1+\tau_{k}\right) k+\left(1+\tau_{a}\right) a-z}{p}+a E\left(\frac{1}{p^{\prime}}\right) .
\end{aligned}
$$

The first-order conditions are

$$
\begin{aligned}
f^{\prime}(k) & =\frac{1+\tau_{k}}{p}+\lambda, \\
E\left(\frac{1}{p^{\prime}}\right) & =\frac{1+\tau_{a}}{p}+\lambda,
\end{aligned}
$$

where $\lambda$ is the shadow cost of constraint $k+a \leq \beta$. The optimal Pigouvian taxes are such that these equations are satisfied for the social planner allocation with $q^{S P}=q\left(k^{S P}, a^{S P}\right)$ and $p^{S P}=p\left(k^{S P}, a^{S P}\right)$ given by (12) and (15). Equations (38) and (39) imply

$$
\tau_{k}-\tau_{a}=p^{S P}\left[f^{\prime}\left(k^{S P}\right)-\left(1-\pi+\frac{\pi}{q^{S P}}\right)\right] .
$$


Equation (40) implies that $\tau_{k}-\tau_{a}$ is uniquely determined and strictly positive. The r.h.s. of (40) is equal to zero if $k^{S P}$ and $q^{S P}$ are replaced by $k^{L F}$ and $q^{L F}$. The fact that $k^{S P}<k^{L F}$ and $a^{S P}>a^{L F}$ implies that $q^{S P}>q^{L F}$ so that the r.h.s. of equation (40) is strictly positive.

One solution has $\tau_{k}=0$ and $\tau_{a}<0$, i.e., the social planner allocation can be implemented with a subsidy on reserves only. To see this note that if $\tau_{k}=0, \tau_{a}$ is given by

$$
\tau_{a}=-p^{S P}\left[f^{\prime}\left(k^{S P}\right)-\left(1-\pi+\frac{\pi}{q^{S P}}\right)\right] .
$$

For this level of taxation the constraint $k+a \leq \beta$ is strictly binding, i.e., $\lambda>0$. This results from (38) and $f^{\prime}\left(k^{S P}\right) p^{S P}>1$, an implication of $f^{\prime}\left(k^{L F}\right) p^{L F} \geq 1, k^{S P}<k^{L F}$ and $p^{S P}>p^{L F}$.

Figure 6 shows the variation of $\tau_{a}$ with $\beta$ under the same calibration as for Figure 4. The subsidy is equal to zero for low levels of financial development where the social planner does not want to accumulate reserves. It jumps to a level in excess of 12 percent and then decreases with the level of financial development towards a limit level of about 2.5 percent. The decrease is because the marginal return on capital, which the subsidy must offset in order to induce reserves accumulation, falls with the level of financial development.

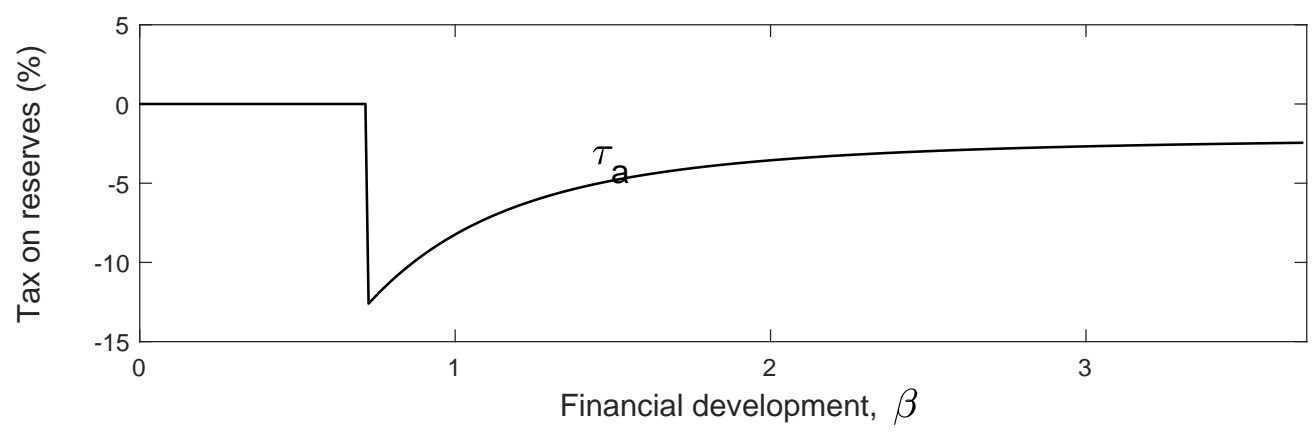

Figure 6: Variation of optimal subsidy on reserves (in percent) with financial development

Capital controls. One can replace the tax on capital by a tax on capital inflows. To see this, let us add a tax on capital inflows $\tau_{b}$ to the set of 
instruments so that the period-0 budget constraint of EM residents becomes,

$$
\left(1+\tau_{k}\right) k+\left(1+\tau_{a}\right) a=\frac{p b}{1+\tau_{b}}+z .
$$

The first-order conditions are now

$$
\begin{aligned}
f^{\prime}(k) & =\frac{\left(1+\tau_{k}\right)\left(1+\tau_{b}\right)}{p}, \\
E\left(\frac{1}{p^{\prime}}\right) & =\frac{\left(1+\tau_{a}\right)\left(1+\tau_{b}\right)}{p} .
\end{aligned}
$$

Any allocation achieved with $\tau_{k}, \tau_{a}$ and $\tau_{b}=0$ can also be achieved with $\widetilde{\tau}_{k}=0, \widetilde{\tau}_{b}=\tau_{k}$ and $\widetilde{\tau}_{a}$ satisfying $\left(1+\widetilde{\tau}_{a}\right)\left(1+\tau_{k}\right)=\left(1+\tau_{a}\right)$. The tax on physical capital is instead applied to capital inflows and the subsidy on reserves is increased by the same amount as the tax on capital inflows to keep the level of reserves unchanged.

\section{A.2 Ex-post interventions}

We have assumed in the text that the social planner does not intervene in period 1. The social planner could however decide to spend less reserves in period 1 than under laissez-faire so as to lower the price at which EM residents buy back debt. Let us assume that the social planner sets the level of interventions $a^{\prime} \leq a$. The fire-sale price of debt is

$$
q=\frac{a^{\prime}+\phi}{b}
$$

In the sudden stop state EM welfare is given by,

$$
U_{1}^{E M}=f(k)-b+\frac{a^{\prime}}{q}+a-a^{\prime},
$$

where $k$ and $b$ are pre-determined. Using (44) to substitute out $q$ and leaving out constant terms, the period-1 social planner's problem can be written,

$$
\max _{a^{\prime} \leq a} \frac{a^{\prime}}{a^{\prime}+\phi} b-a^{\prime}
$$

The solution is

$$
a^{\prime}=\min (a, \sqrt{\phi b}-\phi) .
$$


The social planner uses all the reserves if and only if

$$
a \leq \sqrt{\phi b}-\phi .
$$

If this condition is not satisfied the social planner spends only a fraction of the reserves in period $1 \mathrm{in}$ order to increase the monopoly profit from buying back EM debt at a low price. Using (13) to substitute out $b$ the condition can be rewritten

$$
a(a+\phi) \leq \frac{R^{e}}{1-\pi} \phi(k-\phi) .
$$

When $\beta$ goes to infinity so does $a$ in the social planner allocation (Proposition 6 ). Hence this condition is violated by the social planner allocation for large levels of $\beta$.

\section{B Data Appendix}

The "core EM sample" of countries used in Tables 1 to 4 includes: Argentina, Brazil, Chile, China, Colombia, Egypt, Hungary, India, Indonesia, Malaysia, Mexico, Pakistan, Peru, Philippines, Poland, Russia, South Africa, Thailand, Turkey. The "Large EM sample" also includes: Albania, Angola, Armenia, Bangladesh, Belarus, Bolivia, Bosnia and Herzegovina, Botswana, Bulgaria, Cambodia, Costa Rica, Croatia, Côte d'Ivoire, Dominican Republic, Ecuador, El Salvador, FYR Macedonia, Georgia, Ghana, Guatemala, Honduras, Jamaica, Jordan, Kazakhstan, Kuwait, Kyrgyz Republic, Lesotho, Moldova, Morocco, Myanmar, Namibia, Nicaragua, Nigeria, Panama, Paraguay, Romania, Saudi Arabia, Sudan, Tunisia, Ukraine, Uruguay, Venezuela. 


\section{References}

Adler, Gustavo, and Rui Mano. 2016. "The Cost of Foreign Exchange Intervention: Concepts and Measurement." IMF Working Paper 16/89.

Aizenman, Joshua. 2011. "Hoarding International Reserves versus a Pigovian Tax-cum-Subsidy Scheme: Reflections on the Deleveraging Crisis of 2008-2009, and a Cost Benefit Analysis." Journal of Economic Dynamics and Control, 35(9): 1502-1513.

Aizenman, Joshua, Yin-Wong Cheung, and Hiro Ito. 2015. "International reserves before and after the global crisis: Is there no end to hoarding?" Journal of International Money and Finance, 52: 102-126.

Benigno, Gianluca, Huigang Chen, Christopher Otrok, Alessandro Rebucci, and Eric R Young. 2016. "Optimal capital controls and real exchange rate policies: A pecuniary externality perspective." Journal of Monetary Economics, 84: 147-165.

Bianchi, Javier. 2011. "Overborrowing and Systemic Externalities in the Business Cycle." American Economic Review, 101(7): 3400-3426.

Bianchi, Javier, Juan Carlos Hatchondo, and Leonardo Martinez. 2018. "International Reserves and Rollover Risk." American Economic Review, 108(9): 2629-2670.

Blanchard, Olivier, Gustavo Adler, and Irineu de Carvalho Filho. 2015. "Can Foreign Exchange Intervention Stem Exchange Rate Pressures from Global Capital Flow Shocks?" Manuscript, IMF.

Broner, Fernando, Tatiana Didier, Aitor Erce, and Sergio L Schmukler. 2013. "Gross capital flows: Dynamics and crises." Journal of Monetary Economics, 60(1): 113-133.

Bruno, Valentina, and Huyn Song Shin. 2015. "Cross-Border Banking and Global Liquidity." Review of Economic Studies, 82(2): 535-564. 
Bussière, Matthieu, Gong Cheng, Menzie D. Chinn, and Noémie lisack. 2015. "For a few dollars more: Reserves and growth in times of crises." Journal of International Money and Finance, 52: 127-45.

Caballero, Ricardo J, and Alp Simsek. 2020. "A Model of Fickle Capital Flows and Retrenchment." The Journal of Political Economy, 128(6): 2288-2328.

Caballero, Ricardo J., and Stavros Panageas. 2008. "Hedging Sudden Stops and Precautionary Contractions." Journal of Development Economics, 85: 28-57.

Céspedes, Luis Felipe, and Roberto Chang. 2019. "Optimal Foreign Reserves and Central Bank Policy Under Financial Stress." working paper.

Céspedes, Luis Felipe, Roberto Chang, and Andrés Velasco. 2017. "Financial Intermediation, Real Exchange Rates, and Unconventional Policies in an Open Economy." Journal of International Economics, 108: 7686 .

Davila, Eduardo, and Anton Korinek. 2018. "Pecuniary Externalities in Economies with Financial Frictions." Review of Economic Studies, 85(4): 352-395.

Davis, J. Scott, and Eric van Wincoop. 2017. "Globalization and the Increasing Correlation Between Capital Inflows and Outflows." National Bureau of Economic Research Working Paper 23671.

Forbes, Kristin J, and Francis E Warnock. 2012. "Capital Flow Waves: Surges, Stops, Flight, and Retrenchment." Journal of International Economics, 88(2): 235-251.

Ghosh, Atish R., Jonathan D. Ostry, and Mahvash S. Qureshi. 2016. "When Do Capital Inflow Surges End in Tears?" The American Economic Review, 106(5): 581-585.

Gourinchas, Pierre-Olivier, and Helene Rey. 2007. "From world banker to world venture capitalist: US external adjustment and the exorbitant 
privilege." In G7 current account imbalances: sustainability and adjustment. 11-66. University of Chicago Press.

Gourinchas, Pierre-Olivier, Hélène Rey, and Nicolas Govillot. 2017. "Exorbitant Privilege and Exorbitant Duty." Manuscript, Department of Economics, University of California, Berkeley.

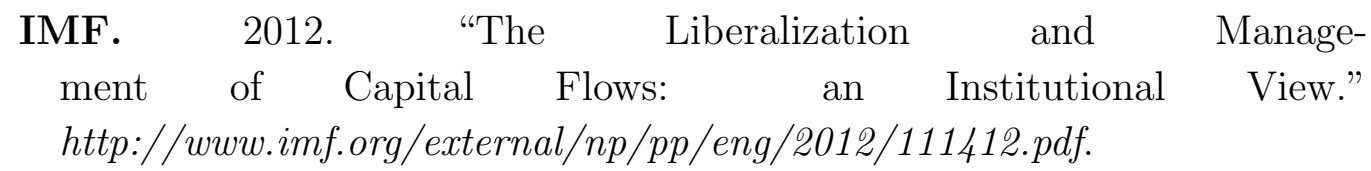

IMF. 2013. "The Yin and Yang of Capital Flow Management: Balancing Capital Inflows with Capital Outflows." World Economic Outlook (Chapter 3, October).

Jeanne, Olivier, and Anton Korinek. 2010. "Excessive Volatility in Capital Flows: A Pigouvian Taxation Approach." American Economic Review Papers and Proceedings, 100(2): 403-7.

Jeanne, Olivier, and Romain Rancière. 2011. "The Optimal Level of Reserves for Emerging Market Countries: Formulas and Applications." Economic Journal, 121(555): 905-930.

Jeanne, Olivier, Arvind Subramanian, and John Williamson. 2012. Who Needs to Open the Capital Account? Peterson Institute for International Economics.

Korinek, Anton. 2011. "The New Economics of Prudential Capital Controls: A Research Agenda." IMF Economic Review, 59: 523-561.

Korinek, Anton. 2018. "Regulating Capital Flows to Emerging Markets: An Externality View." Journal of International Economics, 111: 61-80.

Lane, Philip R, and Gian Maria Milesi-Ferretti. 2007. "A global perspective on external positions." In G7 current account imbalances: sustainability and adjustment. 67-102. University of Chicago Press.

Miranda-Agrippino, Silvia, and Hélène Rey. 2020. "US Monetary Policy and the Global Financial Cycle." Review of Economic Studies. 
Ostry, Jonathan D, Atish R Ghosh, Marcos Chamon, and Mahvash S Qureshi. 2011. "Capital Controls: When and Why?" IMF Economic Review, 59(3): 562-580.

Ostry, Jonathan D, Atish R Ghosh, Marcos Chamon, and Mahvash S Qureshi. 2012. "Managing Capital Inflows: The Role of Capital Controls and Prudential Policies." Journal of International Economics, 88: 407-421.

Rey, Hélène. 2015. "Dilemma Not Trilemma: the Global Financial Cycle and Monetary Policy Independence." National Bureau of Economic Research Working Paper 21162.

Rodrik, D. 2006. "The Social Cost of Foreign Exchange Reserves." International Economic Journal, 20(3): 253-266.

Schmitt-Grohé, Stephanie, and Martín Uribe. 2017. "Is Optimal Capital Control Policy Countercyclical in Open Economy Models with Collateral Constraints?" IMF Economic Review, 65(3): 498-527. 